\title{
A Cross Sectional Survey on Compliance to Antibiotics in Patients with Respiratory Tract Infections in a Tertiary Hospital in Ajman, UAE
}

\author{
Rina Rosalia ${ }^{1, *}$, Nouran Essam Atta ${ }^{1}$, Fithawit Bahran Gebreigziabher ${ }^{1}$, Yahya Salisu ${ }^{1}$, Mubarak Ibrahim \\ Ladan', Amna Shukur', Rizwana Burhanuudin Shaikh², Shatha Al-Sharbatti ${ }^{3}$, Shery Jacob ${ }^{4}$, Salwa Abdelzaher \\ Mabrouk $^{5}$ \\ ${ }^{1}$ College of Pharmacy, Gulf Medical University, Ajman, UNITED ARAB EMIRATES. \\ ${ }^{2}$ Department of Community Medicine, Gulf Medical University, Ajman, UNITED ARAB EMIRATES. \\ ${ }^{3}$ Department, Department of Community Medicine, Gulf Medical University, Ajman, UNITED ARAB EMIRATES. \\ ${ }^{4}$ Department of Pharmaceutics, College of Pharmacy, Gulf Medical University, Ajman, UNITED ARAB EMIRATES. \\ ${ }^{5}$ Department of Internal Medicine, College of Medicine, Gulf Medical University/ Thumbay Hospital, Ajman, UNITED ARAB \\ EMIRATES.
}

Received: 13 April 2019;
Accepted: 17 June 2019
*Correspondence to:
Dr. Rina Rosalia,

Pharm D. Intern, College of Pharmacy, Gulf Medical University, Ajman, UNITED ARAB EMIRATES. Phone no: +971508688679

Email: rosalia17rina@gmail.com Copyright: (C) the author(s),publisher and licensee Indian Academy of Pharmacists. This is an open-access article distributed under the terms of the Creative Commons Attribution Non-Commercial License, which permits unrestricted non-commercial use, distribution, and reproduction in any medium, provided the original work is properly cited.

\begin{abstract}
Background: Compliance to antibiotic regimen is one among several measures required to prevent antibacterial resistance. As there is paucity of published information on compliance to antibiotics in respiratory infections in Ajman, UAE, it is hoped that this study can fill the gap in knowledge. Objectives: 1. To estimate the rate of compliance to antibiotics in patients with respiratory tract infections (RTI). 2. To identify the most frequently prescribed antibiotics for respiratory tract infections. 3 . To determine the extent to which certain factors influence the rate of compliance. 4. To identify the most common side effects associated with antibiotic use. Methods: A cross sectional study was carried out using a validated, self-administered questionnaire which addressed socio-demographic characteristics, Medical history and questions on compliance and reasons for non-compliance. Data was analyzed using SPSS version 24 and Chi-square test was used to test the significance of association. A p-value of $<0.05$ was accepted as a significant level. Results: The study included 260 participants amongst which the majority was men (58.5\%). There was no significant association between the socio-demographic characteristics and the compliance pattern of the participants. Among 260 participants, 180 (69.2\%) reported that they have had an RTI within the past one year and amidst the 180, $172(95.6 \%)$ respondents have been prescribed an antibiotic for their RTI. There was no significant association between patient compliance and the factors that could possibly affect compliance by contributing to skipping medication doses. Out of 172 respondents, 134 (77.9\%) reported that they did not experience any side effects while 38 (22.1\%) participants expressed that they had experienced certain side effects with antibiotic use. The most common side effect reported by the participants was diarrhea (20.5\%) followed by tiredness and drowsiness (each 10.3\%). Conclusion: The participants of the study were found to be mostly compliant to their prescribed antibiotic regimen. There was no significant association between the antibiotic compliance and the socio-demographic characteristics as well as the factors that influence compliance. Majority of the patients were found to be adequately counseled about the importance of antibiotic compliance.
\end{abstract}

Key words: Regimen, Therapy, Non-compliance, Compliance, Adherence, Patient counseling, Antibiotics.

\section{INTRODUCTION}

Compliance or Adherence can be defined as the extent to which a patient is able to follow the prescribed diagnostic treatment or regimen. ${ }^{[1]}$ Many studies have been conducted on therapeutic compliance in cases of chronic diseases but not in acute illnesses such as infectious diseases of the respiratory tract. Respiratory Tract Infections happen to be one of the cardinal reasons why patients seek primary healthcare consultations. ${ }^{[2,3]}$ Poor compliance or Non-compliance to antibiotic regimens forms the basis for treatment failure and poor clinical outcomes. ${ }^{[2]}$ Antibiotic resistance is the ability of a microorganism to withstand the effects of an antibiotic. Antibacterial resistance resulting from inappropriate use of antibiotics makes common or life-threatening infections more difficult or sometimes impossible to treat. Proper adherence to antibiotic therapy is one among several measures required to prevent antibacterial resistance. ${ }^{\left[{ }^{[3]}\right.}$ Antibiotic resistance has become a crucial clinical and public health problem in the present living conditions. Currently, there are a large number of microorganisms that thwart antibiotic therapy due to resistance. ${ }^{[4,5]}$ According to a classification provided by The Centers for Disease Control and Prevention (CDC), a number of bacteria have been categorized to be the causal pathogens of urgent, serious and concerning threats to the patients thereby resulting in substantial clinical and financial burden on the U.S. health care system. ${ }^{[5,6]}$ As a result, the numbers of potent antibiotics have decreased to a point where currently there are only a few antibiotics that are still effective against the resistant pathogens. ${ }^{[4,5,7]}$ 


\section{Rosalia, et al.: Survey on Compliance to Antibiotics in Patients with Respiratory Tract Infections}

Respiratory Tract Infections (RTIs affect the sinuses, throat, airways and lungs. These could be of viral or bacterial origin. Antibiotics are prescribed for bacterial infections and at times as empiric therapy when the causal organism is not identified initially. ${ }^{[8]}$ RTIs are usually classified into Upper Respiratory Tract Infections (URTIs) and Lower Respiratory Tract Infections (LRTIs). Upper Respiratory Tract Infections or URTIs include the most common acute illnesses examined in the outpatient setting. URTIs affect the nose, sinuses and throat, ranging from a mild common cold, to a life-threatening illness such as epiglottitis. ${ }^{[8-10]}$ Other URIs include Sinusitis, Pharyngitis and Laryngotracheitis. Lower Respiratory Tract Infections or (LRTIs) are those which affect the airways and lungs. These include Bronchitis, Bronchiolitis and Pneumonia. ${ }^{[8,9]}$

Patients with acute RTIs are found to be more non-compliant due to several factors. ${ }^{[4,10]}$ Certain factors affecting patient compliance to the prescribed antibiotics include socio-economic conditions of the patients, burdensome work schedules, cost of the medication and complexity of the antibiotic regimen which includes the number of daily doses prescribed, duration of the therapy and side effects that may interfere with the patient's lifestyle. Patient related factors such as physical impairments, cognitive limitations and educational status can also highly influence patient compliance. ${ }^{[4]}$ Moreover, most patients tend to discontinue their antibiotic regimes once they feel their symptoms have slightly subsided and the infection becomes very hard to treat due to the development of resistant strains of bacteria. ${ }^{[4,9]} \mathrm{It}$ is essential that the patients are made aware of the importance of medication adherence and about the consequences associated with non-compliance. ${ }^{[1]]}$ As healthcare professionals, the physicians and pharmacists play a pivotal role in ensuring that the patients adhere to their medication regimes and in spreading awareness to the patients.

Therefore, it is intended that the data collected from this survey will help us to estimate the rate of compliance to antibiotics in patients with respiratory tract infections (RTI) and identify the most frequently prescribed antibiotics for the RTI. We also wanted to identify the most common side effects associated with antibiotic use. In addition, it is hoped that this study would enable us to determine the extent to which certain factors influence the rate of compliance, thereby paving way for the development of new methods to spread awareness to the patients regarding drug compliance and its importance. In addition, it is seen that there is paucity of published information on compliance to antibiotics in respiratory infections; the present study can fill this gap in knowledge.

\section{MATERIALS AND METHODS}

\section{Research Design}

A cross-sectional survey. Study Population: Patients who were attending the Internal Medicine Outpatient Department in Thumbay Hospital Ajman were the prime focus of this study.

\section{Inclusion Criteria}

- Male and female patients attending the internal medicine outpatient department of Thumbay Hospital Ajman and aged more than 18 years.

- Those who accept to participate in the study and sign the informed consent forms

\section{Exclusion Criteria}

Patients aged below 18 years and those who do not sign the informed consent forms at the beginning of the questionnaire.

\section{Sample Size Calculation}

A sample size of 288 participants was calculated using the convenience sampling technique through the formula:

$$
\begin{aligned}
\mathrm{N}= & \frac{\left(\mathrm{z}^{2} \mathrm{pq}\right)}{\mathrm{L}^{2}}, \text { where } \\
\mathrm{P} & =\begin{array}{l}
\text { Population proportion of compliance to antibiotic estimated based } \\
\text { on a study conducted in Saudi Arabia }=75 \%{ }^{[12]}
\end{array} \\
\mathrm{q} & =1-\mathrm{p} \\
\mathrm{L} & =\text { Marginal Error (Usually considering as } 0.05) \\
\mathrm{z} & =\text { Significant level }(95 \% \text { Confidence Interval, } \mathrm{z}=1.96) \\
& =[3.84 \times 0.75 \times 0.25] / 0.0025=288
\end{aligned}
$$

Sampling Method: Convenience sampling.

Study Setting: Internal Medicine Outpatient Department in Thumbay Hospital, Ajman, U.A.E.

Duration of Study: The study was conducted over a period of six months from October 2014 to March 2015.

\section{Study Instrument and Validation Procedure}

A self-administered questionnaire was prepared based on the objectives of this study. The questionnaire was prepared after extensive review of literature and four items were added from the Morisky's self-reported measure of medication adherence scale. ${ }^{[13]}$ It was given to three subject experts from the college of pharmacy; pharmacology and internal medicine department to validate the content. The questionnaire was classified into three domains:

- Socio-demographic characteristics: age, gender, nationality, education and occupation.

- Medical history: details of respiratory infection in the past one year and their respective prescribed antibiotics.

- Questions on compliance and reasons for non-compliance

\section{Ethical issues}

An approval was sought from the Ethics Committee of Gulf Medical University. A written consent was signed by all participants to ensure their acceptance to participate in the survey. Confidentiality of the participants and the research information was assured. The information collected was used only for the research purpose and could be accessed only by the researchers, GMU ethics committee and the department of community medicine. As per the GMU data storage policy, the collected research data and related documents were stored for 3 years in the community medicine department.

\section{Methodology}

- After obtaining an approval from Gulf Medical University Ethics Committee, permission was sought from the management and academic office of Thumbay hospital and Research center, Ajman to undertake the survey.

- Once the information about the nature and purpose of study had been clearly explained to the patients and their consent to participate has been taken, data was collected through self-administered questionnaires. 


\section{Data analysis}

The collected data was entered on a Microsoft Excel Spreadsheet and analyzed using SPSS version 24. The analyzed data was summarized and described in tables and graphs. For associations between variables, Pearson's Chi Square Test was used with a statistical significance level of $p \leq 0.05$.

\section{RESULTS}

The study included a total of 260 participants who were mostly males $(58.5 \%)$. The socio-demographic characteristics of the participants are shown in Table 1. As evident from the table, the participants were predominantly from the age group of 20-29 (37.3\%) and 30-39 (33.1\%). Majority of them were graduates holding a diploma or degree (52.5\%) and have been medically insured (68\%).

Among the 260 participants, $180(69.2 \%)$ reported that they have had an RTI within the past one year and $80(30.8 \%)$ said that they have not. When the 180 participants were further screened, it was identified that amidst the 180, $172(95.6 \%)$ respondents have been prescribed an antibiotic for their respiratory tract infection while $8(4.4 \%)$ were not prescribed an antibiotic. These findings have been depicted in Figures 1 and 2 below.

As per Table 2 given below, among the 172 participants who reported to have been prescribed an antibiotic for their RTI, 68 (39.6\%) respondents were able to recollect their prescribed antibiotic while 104 (60.4\%) could not. On further analysis of the responses of those participants who were able to recollect their prescribed antibiotics (68), the most commonly prescribed antibiotics for respiratory tract infections were identified and are described below in Figure 3.

Moreover, among the 172 participants who had responded to the question regarding patient counseling for appropriate antibiotic use, 103 (59.9\%) respondents have been counseled adequately about antibiotic compliance while $69(40.1 \%)$ reported that they did not receive much information on the same. The above said data is described in Table 3 given below.

Furthermore, as illustrated in Figure 4, the assessment of patient compliance to the prescribed antibiotic revealed that out of the 172 respondents, 112 $(65.1 \%)$ were compliant by reporting that they hardly or never miss their medications. However, $60(34.9 \%)$ reported that they may at times miss a

\begin{tabular}{|c|c|c|c|}
\hline $\begin{array}{l}\text { Socio- } \\
\text { demographic } \\
\text { Characteristics }\end{array}$ & Sub-class & Number & Percentage (\%) \\
\hline \multirow[t]{5}{*}{ Age } & $18-19$ & 19 & 7.3 \\
\hline & $20-29$ & 97 & 37.3 \\
\hline & $30-39$ & 86 & 33.1 \\
\hline & $40-49$ & 40 & 15.4 \\
\hline & 50 and above & 18 & 6.9 \\
\hline \multirow[t]{2}{*}{ Gender } & Male & 145 & 58.5 \\
\hline & Female & 103 & 41.5 \\
\hline \multirow[t]{3}{*}{ Qualification } & School-level & 31 & 12.1 \\
\hline & Diploma/Degree & 135 & 52.5 \\
\hline & Post-graduate & 91 & 35.4 \\
\hline \multirow[t]{2}{*}{ Insurance Status } & Insured & 174 & 68 \\
\hline & Uninsured & 82 & 32 \\
\hline
\end{tabular}

${ }^{*}$ missing data in some variables owing to privacy reasons of the participants.

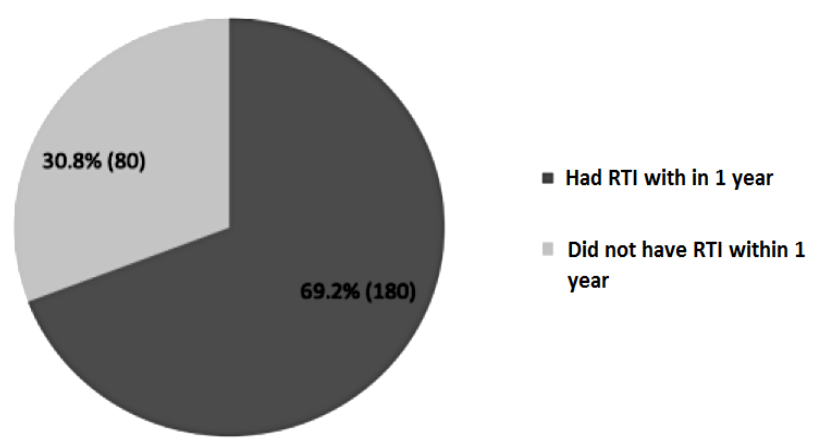

Figure 1: Distribution of Patients who have had RTI within 1 year.

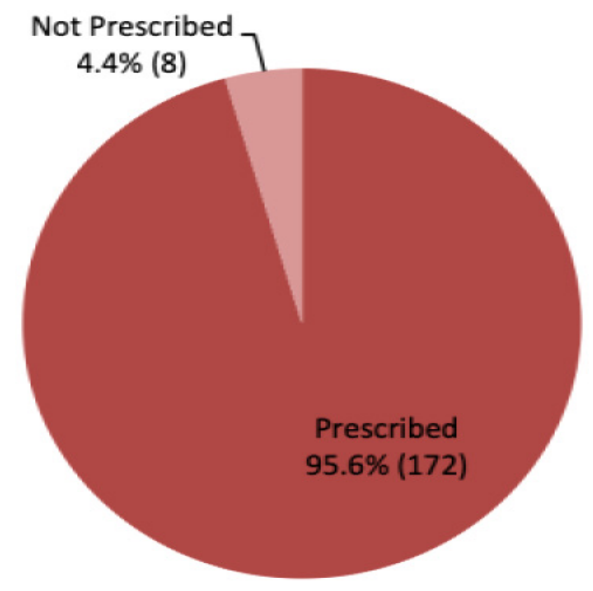

Figure 2: Percentage (No.) of Patients who have been prescribed an Antibiotic for RTI.

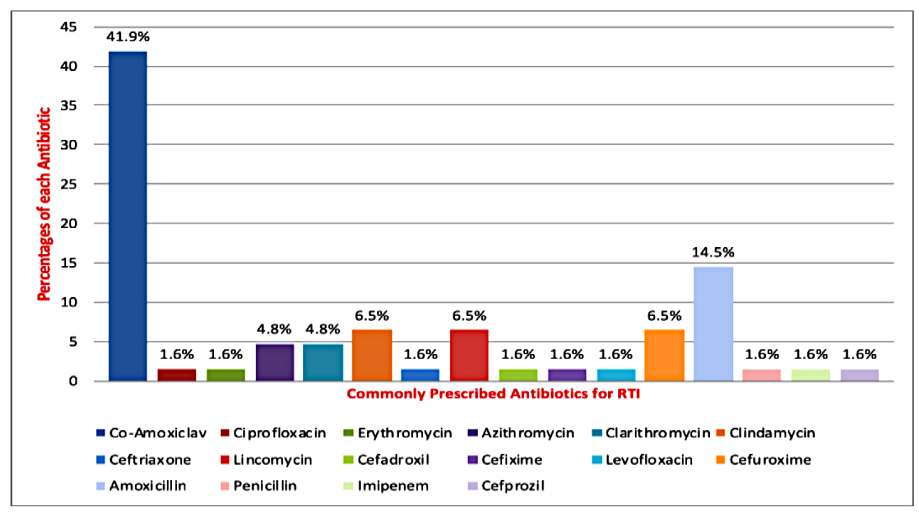

Figure 3: Distribution of Commonly Prescribed Antibiotics for RTI $(\mathrm{N}=68)$.

\section{Table 2: Patients who could recall their Prescribed Antibiotics for RTI ( $\mathrm{N}=172)$.}

\begin{tabular}{|l|l|l|}
\hline \multicolumn{2}{|l|}{ Number } & Percentage \\
\hline Not Able to Recollect the Prescribed Antibiotic & 104 & $60.4 \%$ \\
\hline Able to Recollect the Prescribed Antibiotic & 68 & $39.6 \%$ \\
\hline Total & 172 & $100 \%$ \\
\hline
\end{tabular}


Table 3: Distribution of Patients who have been counseled about the Importance of Compliance $(N=172)$.

\begin{tabular}{|c|c|c|}
\hline \multicolumn{2}{|l|}{ Number } & \multirow{2}{*}{$\begin{array}{l}\text { Percentage } \\
40.1 \% \\
\end{array}$} \\
\hline Not Informed & 69 & \\
\hline Informed & 103 & $59.9 \%$ \\
\hline Total & 172 & $100 \%$ \\
\hline
\end{tabular}

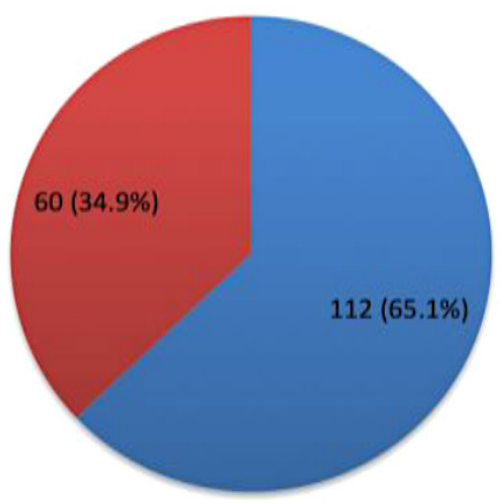

E Compliant

= Non-Compliant

Figure 4: Distribution of Patients Compliance to Antibiotic Regimen $(N=172)$.

dose thereby showing that they were non-compliant.

Table 4 below demonstrates the distribution of compliance vs the factors that influence compliance. Based on these results, it could be deduced that there is no significant association between patient compliance and the factors that could possibly affect compliance by contributing to skipping medication doses. When the individual factors were analyzed, it was identified that there were a few unexpected outcomes. For instance, in case of factor number 2 , among the 28 patients who marked 'yes', $71.4 \%$ were found to be compliant to their medications. We would normally expect the non-compliance rate to be higher if the participants marked 'yes' for a particular factor. Similarly, for factor 1 and 4, the compliance rates $(60.8 \%$ and $61.9 \%)$ are greater than that of non-compliance $(39.2 \%$ and $38.1 \%$ respectively), thereby making them both an unexpected finding. In the cases of the other factors, there is not much difference between the degree of compliance and non-compliance amongst those participants who marked 'yes' for the concerned factors. However, it was seen that the compliance rate was found to be lower $(38.5 \%)$ in patients who reported that they found their antibiotic regimen to be complex and inconvenient.

Table 5 demonstrates the association between the participants' demographic characteristics and the compliance pattern. As seen from the table, there is no significant association between the socio-demographic characteristics and the compliance of the participants. The maximum rate of compliance was found amidst the age group 30-39 years (35.7\%). Males were found to be more compliant than females (63.6\% and $36.4 \%$ respectively). It was also identified that the patients who were graduates holding a diploma or degree and medically insured were more compliant with compliance rates being $55.9 \%$ and $70 \%$ respectively.

Table 6 given below, demonstrates the patient discomfort associated with antibiotic use. Out of 172 respondents, 134 (77.9\%) reported that they did not experience any side effects or discomfort while undergoing therapy with antibiotics. However, 38 (22.1\%) participants expressed that they had experienced certain side effects with antibiotic use, which has been illustrated

\section{Table 4: Distribution of Compliance Vs Factors that} influence Compliance $(\boldsymbol{N}=157)$.

\begin{tabular}{|c|c|c|c|c|c|c|}
\hline $\begin{array}{l}\text { S. } \\
\text { No }\end{array}$ & $\begin{array}{l}\text { Factors } \\
\text { Influencing }\end{array}$ & No. & $\begin{array}{l}\text { Nor } \\
\text { Cor }\end{array}$ & liance & Compliance & $\begin{array}{l}p \\
\text { value }\end{array}$ \\
\hline 1. & $\begin{array}{l}\text { Already feel } \\
\text { better }\end{array}$ & $\begin{array}{l}97 \\
60\end{array}$ & $\begin{array}{l}\text { Yes } \\
\text { No }\end{array}$ & $\begin{array}{l}39.2 \% \\
38.3 \%\end{array}$ & $\begin{array}{l}60.8 \% \\
61.7 \%\end{array}$ & 0.916 \\
\hline 2. & $\begin{array}{l}\text { Antibiotics are } \\
\text { expensive }\end{array}$ & $\begin{array}{l}28 \\
129\end{array}$ & $\begin{array}{l}\text { Yes } \\
\text { No }\end{array}$ & $\begin{array}{l}28.6 \% \\
41.1 \%\end{array}$ & $\begin{array}{l}71.4 \% \\
58.9 \%\end{array}$ & 0.218 \\
\hline 3. & $\begin{array}{l}\text { Sometimes } \\
\text { need a } \\
\text { Reminder } \\
\text { to take } \\
\text { medications }\end{array}$ & $\begin{array}{l}63 \\
94\end{array}$ & $\begin{array}{l}\text { Yes } \\
\text { No }\end{array}$ & $\begin{array}{l}46 \% \\
34 \%\end{array}$ & $\begin{array}{l}54 \% \\
66 \%\end{array}$ & 0.131 \\
\hline 4. & $\begin{array}{l}\text { Do not } \\
\text { always carry } \\
\text { medications } \\
\text { while traveling }\end{array}$ & $\begin{array}{l}42 \\
115\end{array}$ & $\begin{array}{l}\text { Yes } \\
\text { No }\end{array}$ & $\begin{array}{l}38.1 \% \\
39.1 \%\end{array}$ & $\begin{array}{l}61.9 \% \\
60.9 \%\end{array}$ & 0.906 \\
\hline 5. & $\begin{array}{l}\text { Experienced } \\
\text { discomfort } \\
\text { after taking the } \\
\text { antibiotics }\end{array}$ & $\begin{array}{l}29 \\
128\end{array}$ & $\begin{array}{l}\text { Yes } \\
\text { No }\end{array}$ & $\begin{array}{l}44.8 \% \\
37.5 \%\end{array}$ & $\begin{array}{l}55.2 \% \\
62.5 \%\end{array}$ & 0.465 \\
\hline 6. & $\begin{array}{l}\text { Do not believe } \\
\text { that the } \\
\text { antibiotics are } \\
\text { working }\end{array}$ & $\begin{array}{l}16 \\
141\end{array}$ & $\begin{array}{l}\text { Yes } \\
\text { No }\end{array}$ & $\begin{array}{l}50 \% \\
37.6 \%\end{array}$ & $\begin{array}{l}50 \% \\
62.4 \%\end{array}$ & 0.334 \\
\hline 7. & $\begin{array}{l}\text { Antibiotic } \\
\text { regimen are } \\
\text { complex and } \\
\text { cause } \\
\text { inconvenience }\end{array}$ & $\begin{array}{l}13 \\
144\end{array}$ & $\begin{array}{l}\text { Yes } \\
\text { No }\end{array}$ & $\begin{array}{l}61.5 \% \\
36.8 \%\end{array}$ & $\begin{array}{l}38.5 \% \\
63.2 \%\end{array}$ & 0.08 \\
\hline 8. & $\begin{array}{l}\text { Prefer Alternate } \\
\text { Medicine over } \\
\text { Allopathic } \\
\text { Medicine }\end{array}$ & $\begin{array}{l}28 \\
129\end{array}$ & $\begin{array}{l}\text { Yes } \\
\text { No }\end{array}$ & $\begin{array}{l}50 \% \\
36.4 \%\end{array}$ & $\begin{array}{l}50 \% \\
63.6 \%\end{array}$ & 0.182 \\
\hline 9. & $\begin{array}{l}\text { Not properly } \\
\text { informed about } \\
\text { the importance } \\
\text { of Antibiotic } \\
\text { Adherence }\end{array}$ & $\begin{array}{l}16 \\
141\end{array}$ & $\begin{array}{l}\text { Yes } \\
\text { No }\end{array}$ & $\begin{array}{l}43.8 \% \\
38.3 \%\end{array}$ & $\begin{array}{l}56.3 \% \\
61.7 \%\end{array}$ & 0.672 \\
\hline
\end{tabular}

in Figure 5 given below. It was identified that the most common side effect reported by the participants was diarrhea $(20.5 \%)$ followed by tiredness and drowsiness (each 10.3\%).

\section{DISCUSSION}

Medication adherence particularly plays a predominant role in clinical practice. Non-compliance is associated with treatment failure which in turn leads to poor clinical outcomes and several complications such as prolonged duration of illness and increased direct and indirect medical expenses. ${ }^{[2,9,14]}$ In this study, participants who reported that they sometimes or most of the time found it difficult to comply with their antibiotic regimen were grouped into the non-compliant category while those who reported that they rarely or never found any difficulty in compliance were grouped as compliant. On doing so, it was identified that $112(65.1 \%)$ were compliant to their antibiotic regimen. However, in a study by Llor C et al..$^{\left[{ }^{9]}\right.}$ it was found that antibiotic compliance measured by the self-reported compliance question was exceptionally greater than that objectively determined by the MEMS (Medication Event Monitoring System), indicating that self-reporting seems to be prone to overestimation of true compliance. The possible explanation behind this "pseudo" compliance result could be that patients may not want to admit that they are non-compliant and hence reported compliance. ${ }^{[9]}$ Hence, there could be a possibility that even in this study, the compliance rate was overestimated. 
Rosalia, et al.: Survey on Compliance to Antibiotics in Patients with Respiratory Tract Infections

Table 5: Association between Compliance and Socio-demographic Characteristics of the Participants.

\begin{tabular}{|c|c|c|c|c|c|}
\hline \multirow{2}{*}{$\begin{array}{l}\text { Socio } \\
\text { Demographic } \\
\text { Characteristics }\end{array}$} & \multirow[b]{2}{*}{ Sub-class } & \multicolumn{2}{|c|}{ Compliance Rates } & \multirow[b]{2}{*}{$\begin{array}{l}\text { Total } \\
(n)\end{array}$} & \multirow[b]{2}{*}{$p$ value } \\
\hline & & $\begin{array}{l}\text { Non } \\
\text { Compliance } \\
\text { No. (\%) }\end{array}$ & $\begin{array}{l}\text { Compliance } \\
\text { No. (\%) }\end{array}$ & & \\
\hline \multirow[t]{5}{*}{ Age } & Less than or equal to 19 & $3(4.5)$ & $7(6.3)$ & 10 & \multirow{5}{*}{0.920} \\
\hline & $20-29$ & $19(28.7)$ & $36(32.1)$ & 55 & \\
\hline & $30-39$ & $27(40.9)$ & $40(35.7)$ & 67 & \\
\hline & $40-49$ & $13(19.6)$ & $24(21.4)$ & 37 & \\
\hline & 50 and above & $4(6.3)$ & $5(4.5)$ & 9 & \\
\hline \multirow[t]{2}{*}{ Gender } & Male & $33(52.4)$ & $68(63.6)$ & 101 & \multirow[t]{2}{*}{0.152} \\
\hline & Female & $30(47.6)$ & $39(36.4)$ & 69 & \\
\hline \multirow[t]{3}{*}{ Qualification } & School-level & $10(15.4)$ & $7(6.3)$ & 17 & \multirow{3}{*}{0.066} \\
\hline & Diploma/Degree & $27(41.5)$ & $62(55.9)$ & 89 & \\
\hline & Post-graduate & $28(43.1)$ & $42(37.8)$ & 70 & \\
\hline \multirow[t]{2}{*}{ Insurance Status } & Insured & $47(73.4)$ & $77(70)$ & 124 & \multirow[t]{2}{*}{0.386} \\
\hline & Uninsured & $17(26.6)$ & $33(30)$ & 50 & \\
\hline
\end{tabular}

\begin{tabular}{|c|c|c|}
\hline \multicolumn{2}{|l|}{ Number } & \multirow{2}{*}{$\begin{array}{l}\text { Percentage (\%) } \\
77.9 \% \\
\end{array}$} \\
\hline Not Experienced any Discomfort & 134 & \\
\hline Experienced Discomfort & 38 & $22.1 \%$ \\
\hline Total & 172 & $100 \%$ \\
\hline
\end{tabular}

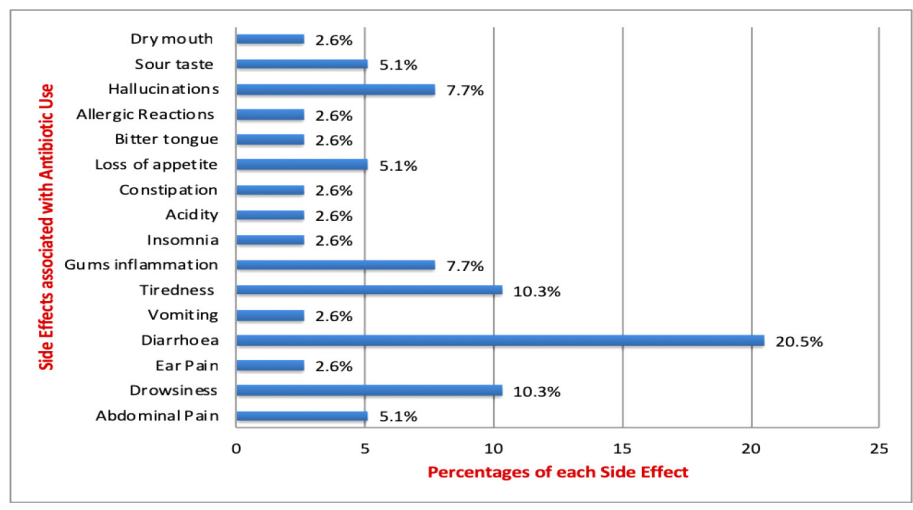

Figure 5: Distribution of Side Effects Associated with Antibiotic Use $(\mathrm{N}=38)$.

Furthermore, we found that there was no significant association between the factors that contributed towards skipping antibiotic doses and the compliance rate of the participants. The rate of compliance was found to be higher amidst participants who reported that factors $1(60.8 \%), 2(71.4 \%)$ and $4(61.9 \%)$ could have contributed towards their non-compliance. It was expected that the non-compliance rate would be higher when the participants agreed that a certain factor was contributing for their skipping doses. However, the rate of compliance was higher amongst these patients who marked 'yes' for all 3 factors. Hence, these findings could be deemed as unexpected. The possible explanation for these unexpected findings would be that although the patients considered these factors to have an effect on their compliance pattern, they remained adherent to their antibiotic regimen perhaps due to their prior encounters with the same RTI and antibiotics or due to the effective patient counseling that they may have received from their healthcare providers. As mentioned previously, the proportion of patients who reported that they had been adequately counseled about the importance of compliance was 103 $(59.9 \%)$ out of 172 patients who had been prescribed antibiotics. Moreover, a 2012 systematic review by Viswanathan et al. ${ }^{[15]}$ that evaluated interventions to improve adherence to self-administered medications for chronic disease, revealed that enhanced patient education on compliance and incorporation of a team-based care and care coordination, involving pharmacists and nursing staffs improved adherence in more than one condition. Also, in a literature review done by Eaddy MT et al. ${ }^{[16]}$ it was identified that lowering copayments of health insurances had a positive impact on medication adherence. ${ }^{[15-17]}$ In our study, the patients who reported that antibiotics were expensive in factor 2, were yet found to be highly compliant $(71.4 \%)$ to their antibiotics. The probable reason behind this finding would be because these patients had health insurances that had lower copayments. Hence, the patients had reduced out-of-pocket patient costs (ROPC), which thereby increased their compliance rates.

In other studies, by Llor $\mathrm{C}$ et al. and Kardas $\mathrm{P}$, the findings proved that the degree of compliance was greater amidst patients with an antibiotic regimen of once a day or twice a day dosing. ${ }^{[2,9,14,18]}$ The rate of compliance was very low especially when antibiotics were administered thrice daily and in regimens of 7 days or more. Likewise, in our study the compliance rate was found to be lower $(38.5 \%)$ in patients who reported that they found their antibiotic regimen to be complex and inconvenient. The most frequent error that occurs with thrice a day dosing is that majority of the patients skip a dose of their antibiotic, which is mostly the afternoon dose. On doing so, the plasma concentration of the antibiotic falls low enough to prevent its inhibitory action on the bacteria but remains high enough for the development of selection pressure and antibiotic resistance. ${ }^{[2,18,19]}$

Furthermore, in a survey conducted on antibiotic utilization and adherence pattern in Ajman, U.A.E with 233 participants, it was seen that $56 \%$ of the lot didn't seek pharmacists' advice and were found to be non-compliant to their antibiotic regimens and lacked awareness about the consequences associated with improper antibiotic use and non-adherence. ${ }^{[20]}$ On the other hand, in our study, the patients were found to be predominantly compliant to their antibiotic therapy and claimed to have received appropriate counseling on compliance. Therefore, it is clearly evident that hospital consultations and 
patient counseling play major roles in enhancing compliance. Nevertheless, in our study, the insurance status did not have much influence on the compliance rates of the participants. It was also identified that the highest degree of adherence to prescribed medications was seen amongst those participants holding a diploma or undergraduate degree, indicating that educational status had an impact on compliance up to a certain extent.

\section{Recommendations}

It is imperative to be noted by all healthcare providers that patient compliance to drug therapy does not entirely depend on the patients alone. The health care providers also play a pivotal role in ensuring patient compliance. Interventions like simplification of antibiotic regimen, imparting awareness about the consequences of non-adherence via effective patient counseling, evaluating adherence and providing timely reminders via phone calls or emails are effective ways in which patient compliance can be improved. ${ }^{[4,11,15]}$ Thus, the results of this research is expected to enhance the effective spreading of awareness about patient compliance and pave way for the development of better treatment strategies for respiratory tract infections in the United Arab Emirates.

\section{Limitations of the study}

As the research was carried out among a small section of the population of Ajman, United Arab Emirates, it is not possible to generalize the results. Since, our questionnaire is self-reported; there could be an influence of recall bias. Also, due to time constraints, the target sample size of 288 could not be achieved and the data analysis was done on the responses of 260 participants who filled the questionnaire.

\section{CONCLUSION}

The participants of the study were found to be mostly compliant to their prescribed antibiotic regimen. There was no significant association between the antibiotic compliance and the socio-demographic characteristics as well as the factors that influence compliance. Majority of the patients were found to be adequately counseled about the importance of antibiotic compliance.

\section{ACKNOWLEDGEMENT}

First and foremost, I would like to extend our gratitude towards Dr. Rizwana Burhanuudin Shaikh, our main supervisor for her guidance and support towards the development of this study. Secondly, I would like to thank our co-supervisors Dr. Shery Jacob, College of Pharmacy, Gulf Medical University and Dr. Salwa Abdelzaher Mabrouk, Department of Internal Medicine, Thumbay Hospital Ajman for their guidance throughout the course of this research. Finally, I owe my heartfelt gratitude to Professor Shatha Al-Sharbatti, Department of Community Medicine, Gulf Medical University, for assisting us in data analysis and for her immense encouragement towards the completion of this study.

\section{CONFLICT OF INTEREST}

The authors declare no conflict of interest.

\section{ABBREVIATIONS}

None.

\section{REFERENCES}

1. Katzung BG. Basic and Clinical Pharmacology. $8^{\text {th }}$ rev ed. New York: Lange Medical Books, McGraw-Hill. 2007.

2. Llor C, Sierra N, Hernandez S, Moragas A, Hernandez M, Bayona C, et al. The higher the number of daily doses of antibiotic treatment in lower respiratory tract infection the worse the compliance. J Antimicrob Chemother. 2008;63(2):396-9.

3. Axelsson M. Report on personality and adherence to antibiotic therapy a population-based study. BMC Psych. 2013;1(2):1-6.

4. Kalogianni A. Factors affect in patient adherence to medication regimen. HSJ. 2011;5(3):157-8.

5. Ventola CL. The Antibiotic Resistance Crisis: Part 1: Causes and Threats. Pharmacy and Therapeutics. 2015;40(4):277-83.

6. Centers for Disease Control and Prevention, Office of Infectious Disease Antibiotic resistance threats in the United States. 2013.

7. Levy SB. Factors impacting on the problem of antibiotic resistance. J Antimicrob Chemother. 2002;49(1):25-30.

8. Patton KT, Thibodeau GA. Anatomy and Physiology. $7^{\text {th }}$ rev ed. St. Louis: Mosby Elsevier. 2010.

9. Llor C, Hernandez S, Bayona C, Moragas A, Sierra N, Hernández M, et al. A study of adherence to antibiotic treatment in ambulatory respiratory infections. Int Jour Infect Dis. 2013;17(3):168-72.

10. Longo DL, Fauci AS, Kasper DL. Harrison's principles of internal medicine. $18^{\text {th }}$ rev ed. New York: McGraw-Hill. 2012;1277.

11. McDonald HP, Garg AX, Haynes RB. Interventions to enhance patient adherence to medication prescriptions. Americ Medic Associat. 2002;288(22):2868-79.

12. Shariff A, AIDhubaib BE, AINowis A, AlHaddad F, AIOmran N, AlKhuliteet $\mathrm{H}$. Statistical investigation of patient factor in development of antibiotic resistance-A Study in Eastern Province of Saudi Arabia. Int J Pharm Pharm Sci. 2013;5(2):151-6.

13. Morisky DE, Green LW, Levine DM. Concurrent and predictive validity of a selfreported measure of medication adherence. Medical Care. 1986;24(1):67-74.

14. Kardas P. Patient compliance with antibiotic treatment for respiratory tract infections. J Antimicrob Chemother. 2002;49(6):897-903.

15. Vishwanathan $M$, Golin $C E$, Jones $C D$, et al. Interventions to improve adherence to self-administered medications for chronic diseases in the United States: a systematic review. Ann Intern Med. 2012;157(11):785-95.

16. Eaddy MT, Cook CL, O'Day K, Burch SP, Cantrell CR. How Patient Cost-Sharing Trends Affect Adherence and Outcomes: a Literature Review. Pharmacy and Therapeutics. 2012;37(1):45-55.

17. luga AO, McGuire MJ. Adherence and health care costs. Risk Management and Healthcare Policy. 2014;7:35-44.

18. Kardas P. Comparison of patient compliance with once-daily and twice-daily antibiotic regimens in respiratory tract infections: results of a randomised trial. J Antimicrob Chemother. 2007;59(3):531-6.

19. Vrijens B, Urquhart J. Patient adherence to prescribed antimicrobial drug dosing regimens. J Antimicrob Chemother. 2005;55(5):616-27.

20. Hamoudi NM, Vanama J, Al-Ayoubi ID. Antibiotics utilization and adherence pattern in Ajman/UAE. J App Pharm Sci. 2012;02(06):213-6.

Cite this article as: Rosalia R, Atta NE, Gebreigziabher FB, Salisu Y, Ladan MI, Shukur A, et al. A Cross Sectional Survey on Compliance to Antibiotics in Patients with Respiratory Tract Infections in a Tertiary Hospital in Ajman, UAE. J Pharm Pract Community Med. 2019;5(2):438. 